\title{
Protein Purification in Chromatographic Media using Multiwall Carbon Nanotubes
}

\section{Mubarak NM ${ }^{1,2 *}$ and Faridah $\mathrm{Y}^{3}$}

${ }^{1}$ Department of Chemical Engineering, Faculty of Engineering, University of Malaya, Malaysia

${ }^{2}$ Department of Chemical and Petroleum Engineering, Faculty of Engineering, UCSI University Kuala Lumpur-56000, Malaysia

${ }^{3}$ Department of Biotechnology Engineering, Faculty of Engineering, International Islamic University Malaysia, Kuala Lumpur, Malaysia

\begin{abstract}
Carbon Nanotubes (CNTs) had been synthesized by Double Stage Chemical Vapor Deposition (DS-CVD) at the gas phase with Hydrogen gas $\left(\mathrm{H}_{2}\right)$ and acetylene $\left(\mathrm{C}_{2} \mathrm{H}_{2}\right)$ as precursor gases. Moreover, the structure of CNTs, morphology and purity were characterized by using the Transmission Electron Microscope (TEM), Field Emission Scanning Electron Microscope (FESEM) and Thermogravimetric Analysis (TGA). Furthermore, the best conditions for the optimal CNT was reaction at temperature of $750^{\circ} \mathrm{C}$, reaction time of 30 minutes, with gas flow rates $\mathrm{H}_{2}$ and $\mathrm{C}_{2} \mathrm{H}_{2}$ for 60 and $170 \mathrm{ml} / \mathrm{min}$ for respectively. The hydrochloric acid was used to purify produced CNT and then using the nitric acid and sulfuric treatment to functionalize. Moreover, functionalized CNTs, non-functionalized were used as column chromatographic media for skim latex protein purification. Thus, the results reveal that at $\mathrm{pH} 7$ and ionic strength $50 \mathrm{mM}$ gives higher efficiency of protein removal from the skim latex (Graphical abstract (Figure 1)).
\end{abstract}

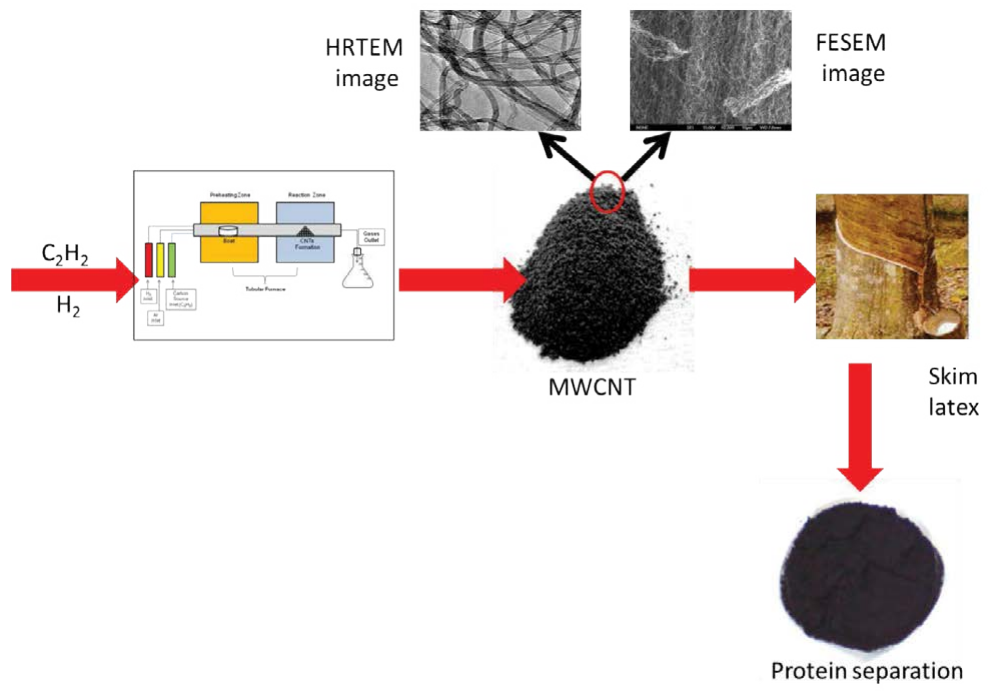

Graphical abstract: Synthesis and characterization of MWCNTs for protein purification.

Keywords: CNTs; DS-CVD; Functionalization; Skim latex serum; Protein purification

\section{Introduction}

Firstly, Carbon Nanotubes (CNTs) were a breakthrough of material that had gained great attention since its discovery by Iijima in 1991 [1]. CNTs had continued to receive a huge interest because their extraordinary mechanical [2], thermal [3], magnetic and electrical properties $[4,5]$. They had been investigated and had been a wide range of applications. In special, electrochemical and electronic applications were most promising, and include Field Emission Displays (FEDs) [6], nano electronic devices [7], chemical sensors [8], hydrogen storage $[9,10]$ and scanning probe tip [11]. Several methods to grow CNTs had been developed, including laser ablation [12], arc discharge [13] and Chemical Vapor Deposition (CVD) [14]. Many attempts [15-26] have been made to solubilise and disperse CNTs in suitable solvents to broaden the applications of CNTs in the field of nanotechnology, purification and manipulation. In this study, double stage Chemical Vapor Deposition (DS-CVD) with acetylene $\left(\mathrm{C}_{2} \mathrm{H}_{2}\right)$ and hydrogen $\left(\mathrm{H}_{2}\right)$ as the precursor gases were used to produce the product of CNTs. The best CNTs yield was produced in terms of the amount and purity, the process parameters were statistically optimized with respect to reaction temperature, gas flow rates for $\mathrm{C}_{2} \mathrm{H}_{2}$ and $\mathrm{H}_{2}$ and reaction time.

Secondly, the process of purification was applied for the optimal Produced CNT to remove unused impurity, such as left over catalyst, via oxidation with nitric acid and sulfuric acid after which they were

*Corresponding author: Mubarak NM, Department of Chemical Engineering Faculty of Engineering, University of Malaya, Kuala Lumpur -50603 Malaysia, Tel: 060-391-018-80 (Ext-5004); Fax: +603-913-236-63; E-mail: mubarakmujawar@ucsiuniversity.edu.my

Received January 24, 2015; Accepted March 13, 2015; Published March 17 2015

Citation: Mubarak NM, Faridah Y (2015) Protein Purification in Chromatographic Media using Multiwall Carbon Nanotubes. J Bioprocess Biotech 5: 214 doi: 10.4172/2155-9821.1000214

Copyright: @ 2015 Mubarak NM, et al. This is an open-access article distributed under the terms of the Creative Commons Attribution License, which permits unrestricted use, distribution, and reproduction in any medium, provided the original author and source are credited. 
Citation: Mubarak NM, Faridah Y (2015) Protein Purification in Chromatographic Media using Multiwall Carbon Nanotubes. J Bioprocess Biotech 5: 214 doi: $10.4172 / 2155-9821.1000214$

Page 2 of 9

then functionalized. Moreover, the report was shown that used the acid washing for the purification of CNT creates open end termini in the structure that were stabilized by the carboxyl and hydroxyl groups left bonded to the nanotube at the end termini and the sidewall defect sites [27]. Moreover, carboxylic group may also be introduced at the tube surface which may covalently bind proteins. This process of diimideactivated amidation between the carboxylic acid groups on the surface CNTs and amine groups on proteins could be carried out using a two-step. A media for column chromatography were applied as these functionalized CNTs as well as the non-functionalized batches. This is because its nano-sized dimensions, CNTs would provide a large surface area, making it more fitting media to purify proteins.

Lastly, we purposed the use of CNTs to purify proteins sourced from skim latex serum. Moreover, skim latex serum was recovered from skim latex, a by-product of natural latex industries, which were usually considered as a waste, thus lavishly thrown away. Furthermore, it was contained a dry rubber content of between 3 to $7 \%$ with very low dirt content. Thus, Skim latex serum was the non-rubber aqueous portion of latex as a result of acid coagulation or membrane filtration. Moreover, the serum was contained a rich source of nitrogen, carbohydrates, proteins, lipids and trace metals. Moreover, some of these proteins were important enzymes which had enormous demand in pharmaceutical, food and detergent industries. CNTs have many uses and this work adds to another dimension in the numerous applications of CNTs. Hence, there was a need in the art to improve the efficiency and yield of protein separation [28].

\section{Preparation of Skim Latex Serum}

The skim latex serum was prepared by submit skim latex to the process of acidification by acetic acid to promote the coagulation of small rubber particles and then centrifugation at 10,000 RPM was carried out which leads to separation of cell debris, clear serum and coagulated latex. After that, to remove the low molecular weight solutes by the clear serum was submitted to dialysis (with $10 \mathrm{kD}$ MWCO) against a buffer solution.

\section{Purification of Skim Latex by CNTs}

The CNT was mixed with $20 \%$ alcohol for the column preparation, the CNT suspension was poured into a Bio-Rad (USA) column measuring $(1 \times 10 \mathrm{~cm})$ to a height of $2 \mathrm{~cm}$ and then washed with 5 column volumes of distilled water and further equilibrated with 3 column volumes of running buffer, $50 \mathrm{mM}$ Tris- $\mathrm{HCl}, \mathrm{pH}$ 7.0. The AKTA prime (GE, Healthcare, USA) liquid chromatography system was collected for the purification processes. We performed that the

\begin{tabular}{|c|c|c|}
\hline Steps & $\begin{array}{c}\text { Non functionalization } \\
\text { of } \mathbf{C N T s}(\mathbf{m l})\end{array}$ & $\begin{array}{c}\text { Functionalization } \\
\text { of CNTs }(\mathbf{m l})\end{array}$ \\
\hline Equilibrium & 10 & 10 \\
\hline Sample size & 2 & 2 \\
\hline Wash 1 & 20 & 20 \\
\hline Elution & 40 & 40 \\
\hline Wash2 & 10 & 10 \\
\hline Per fraction & 2 & 2 \\
\hline & Table 1: Buffer required volumes. \\
\hline
\end{tabular}

process of purification of skim latex serum by using functionalized CNT column and also compared the performance to the non-functionalized CNTs column. Moreover, the functional group that existed on the CNT in both cases we performed the process of purification on functionalized CNTs as in Ion Exchange Chromatography (IEC) procedure. Furthermore, the purification process by non functionalized CNTs was leaded as in Hydrophobic Interaction Chromatography (HIC). Thus, the functionalized carbon nanotubes were stirred and homogenized with the binding buffer (Buffer A) inside the column for the column preparation. Moreover, it was cleaned by the distilled water and two times binding buffer when the column was packed. Thus, $\mathrm{pH}$ and concentration of the binding buffer must be identical to the sample. For functionalized CNTs, the skim latex sample would be dialyzed against binding buffer that did not contain ammonium sulphate and eluted by buffer that contains $2 \mathrm{M}$ ammonium sulphate. Moreover, the method templates used to be the ion exchange/gradient elution to perform this ion exchange chromatography. For the AKTA prime system, the volumes of buffer required for each step of the purification were set accordingly as tabulated in Table 1. Automatically, the column was equilibrated with predetermined $\mathrm{pH}$ and ionic strength of each buffer. The column was finally elected with a linear gradient of $2 \mathrm{M}$ ammonium sulfate.

For the filtration of skim latex serum using hydrophobic interaction chromatography for the column preparation was identical to the ion exchange chromatography except in this type of chromatography; the non-functionalized CNTs would be used as the columns resin. Moreover, it was washed with the distilled water two time binding buffer when the column was packed; $\mathrm{pH}$ and the concentration of the binding buffer must be identical to the sample. Thus, the skim latex sample would be dialyzed against binding buffer that did contain $2 \mathrm{M}$ ammonium sulphate and eluted by buffer that did not contain any salt for nonfunctionalized CNTs. Moreover, the method templates used was the hydrophobic interaction chromatography/gradient elution to perform this hydrophobic interaction chromatography. Thus, the binding buffers
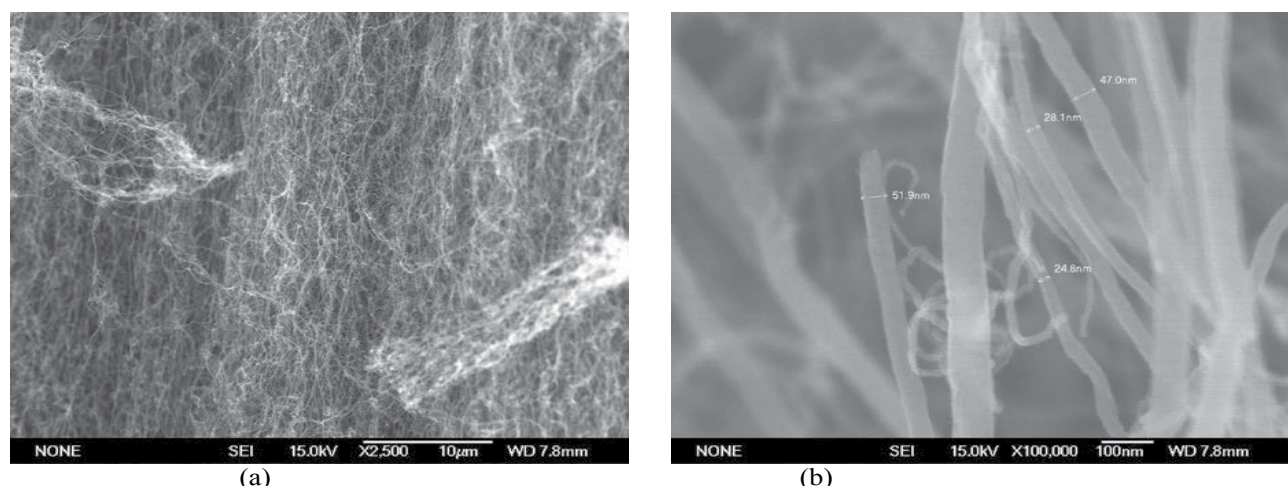

(b)

Figure 2: FESEM images of CNTs produced at reaction temperature $850^{\circ} \mathrm{C}$ with different magnifications. 
Citation: Mubarak NM, Faridah Y (2015) Protein Purification in Chromatographic Media using Multiwall Carbon Nanotubes. J Bioprocess Biotech 5: 214 doi: $10.4172 / 2155-9821.1000214$

Page 3 of 9

for each case were different when comparing the capacity between functionalized and non-functionalized CNTs as chromatographic media. Moreover, binding buffer for non-functionalized CNT included $2 \mathrm{M}$ ammonium sulfate as the neutral salt. Serum samples for both chromatography's were synchronized accordingly. Fractions of $2 \mathrm{ml}$ each were collected during the elution period.

\section{Results and Discussion}

\section{Characterization of the produced CNTs}

The results show that high purity and high yield of CNTs reveal that we have success. The CNTs were then characterized by using FESEM, TEM, TGA and FTIR. FESEM images in Figures $2 \mathrm{a}$ and $2 \mathrm{~b}$ show that the non-functionalized CNTs before functionalization at different magnifications, i.e. 1000 and 1000,000 nm scale. Moreover, the images show that the produced CNTs were the vertical alignment of CNTs could be observed with the diameter of CNTs ranging from 31-36 nm. Thus, at low magnification some of impurities such as amorphous carbon and excess catalyst particles could be seen on the surface of CNTs. These high yield and high purity CNTs could be further used in protein purification. The total amounts of CNTs produced were calculated by weighing the initial weight of the sample (catalyst) and after the carbon nanotube synthesis according to the following equation 1 .

CNTs yield $=\left(M_{\mathrm{f}}-\mathrm{M}_{\mathrm{i}}\right) / \mathrm{M}_{\mathrm{i}}$

Where, $M_{f}$ is the total weight of CNTs obtained (mg), $M_{i}$ is the weight of the catalyst after reduction.

Figures $3 \mathrm{a}$ and $3 \mathrm{~b}$, FESEM images shows that after functionalization of CNTs at the reaction temperature of $850^{\circ} \mathrm{C}$ with the different magnification scales $(1 \mu \mathrm{m}$ and $100 \mathrm{~nm})$, it could be clearly observed that oxidized CNTs appeared shorter than raw CNTs. Moreover, the surface of the raw CNTs was smoother than the oxidized CNTs because the agglomeration of CNTs tube affected by the acid treatment. The figure shows that the surface of CNTs became agglomerated, which created open end that could be attached to the functional group was possibly formed, especially on the walls and any available defective sites. These functional groups could be carboxylic or amine groups.

Based on the Figure 4a shows the High Resolution Transmission Electron Microscope (HRTEM) images of the production of CNTs at a reaction temperature of $850^{\circ} \mathrm{C}$ at different magnification scale. Moreover, it was carried out to characterize the structure of nanotubes. Based on the images, it was observed that all the nanotubes were hollow and tubular in shape. Some of the images, catalyst particles, and an arrow could be seen trapped inside the carbon nanotubes. According to Figure $4 \mathrm{~b}$, shows the HRTEM images of CNTs at a reaction temperature of $850^{\circ} \mathrm{C}$ at different magnification scale. Based on Figure $4 \mathrm{~b}$, a highly ordered crystalline structure of CNTs was observed. Moreover, the clear fringes of graphite sheets were well separated by $10 \mathrm{~mm}$ and aligned with a tilted angle of about $2^{\circ}$ to the tube axis. Thus, the HRTEM image shows that there were about 19 graphitic walls of the multi layers CNTs grown at $850^{\circ} \mathrm{C}$. Hence, the CNTs were observed to be multi-walled.

Based on Figure 5, shows the FTIR spectra (Perkin elemer ATR method) of CNTs of before and after functionalization. Moreover, the results indicated that the functionalization has been successfully occurred on the surface of CNTs. Although quite broad, the process of the absorption peak by the carboxylic group could be observed at
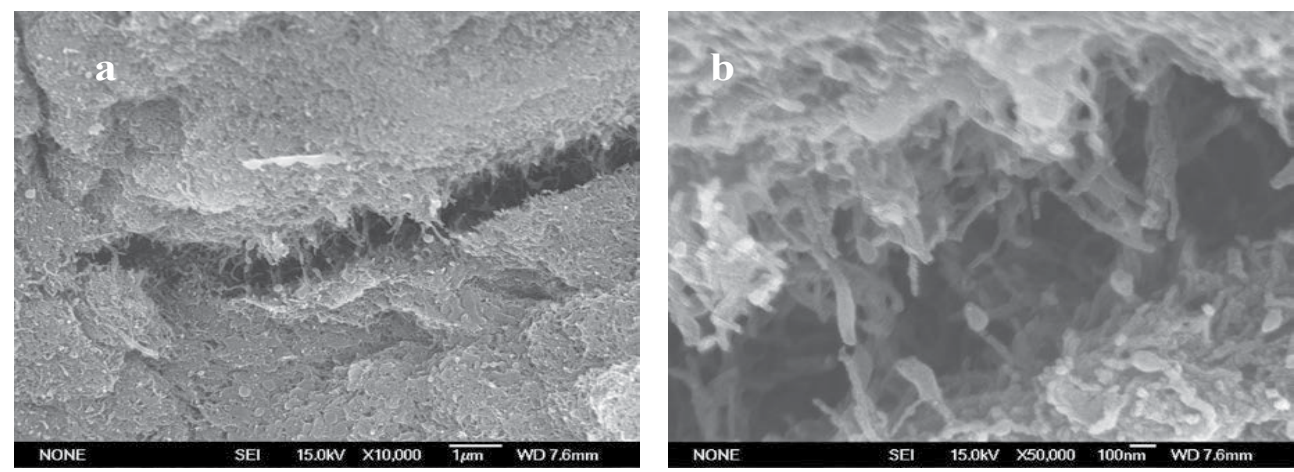

Figure 3: FESEM images of CNTs produced at reaction temperature $850^{\circ} \mathrm{C}$ with different magnifications after functionalization.
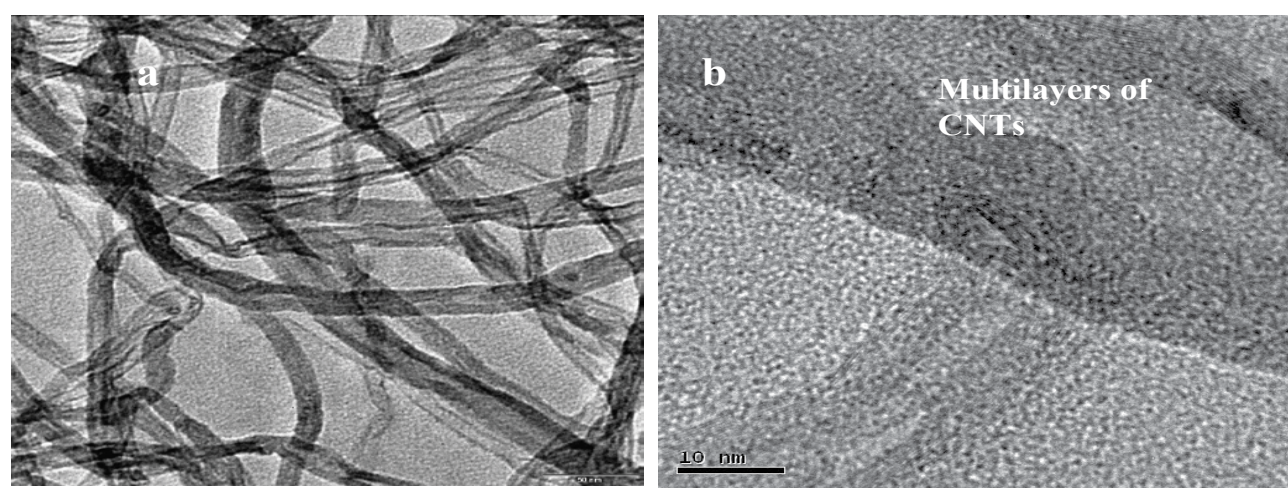

Figure 4: TEM images of CNTs at reaction temperature $850^{\circ} \mathrm{C}$ with different magnifications. 


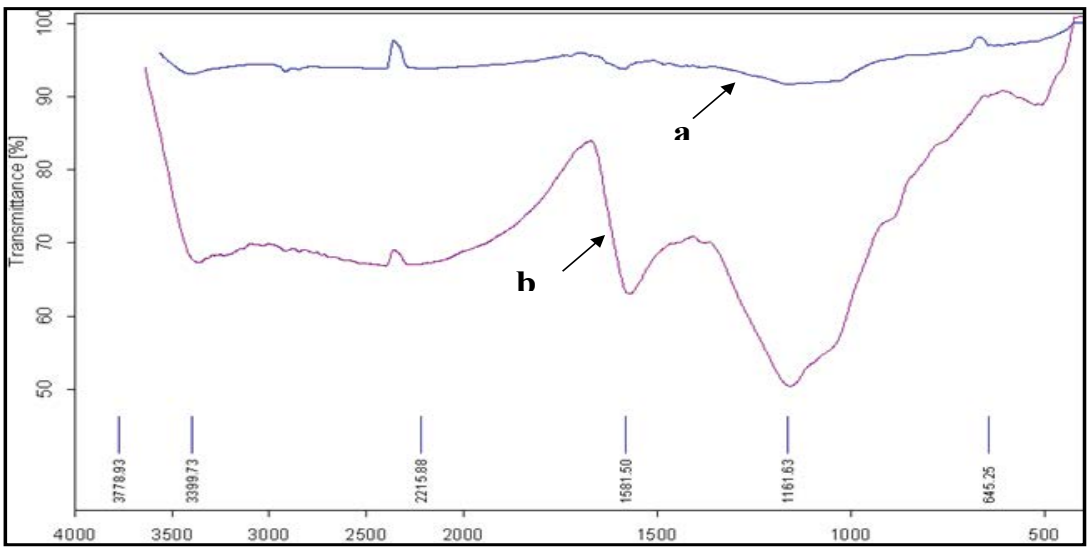

Figure 5: FTIR Absorption Spectra, a) Non-functionalized CNTs, b) Functionalized CNTs.

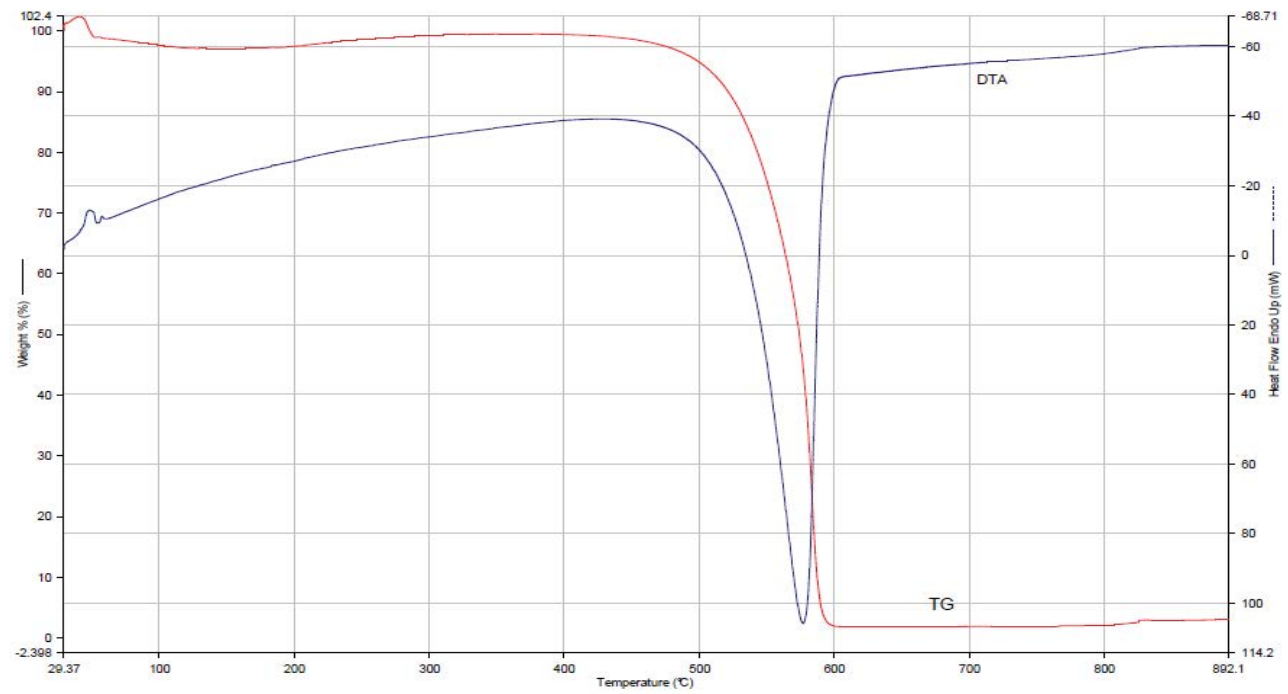

Figure 6: TGA analysis of the selected CNT produced at optimal conditions.

range 1700 to $1900 \mathrm{~cm}^{-1}$. This is in accordance to the values given in the literature [29].

\section{Thermogravimetric analysis}

To examine the purity of the selected CNT was used by the method of TGA of the non-functionalized CNT. Moreover, the variations of the $\mathrm{CNT}$ mass with respect to temperatures at specific time were shown in Figure 6. Based on the TGA analysis shows a single peak at $500^{\circ} \mathrm{C}$, implying high purity of the CNT. Moreover, the peak corresponds to the decomposition of one element only (carbon), since no other peaks were observed. Thus, there was a very slight loss of weight between $50^{\circ} \mathrm{C}$ to $200^{\circ} \mathrm{C}$, which correspond to the loss of water from the catalyst support. Moreover, the weight loss from temperature of $500^{\circ} \mathrm{C}$ to $650^{\circ} \mathrm{C}$ was because the oxidation of the CNT. Furthermore, the flat profile between $650^{\circ} \mathrm{C}$ and $850^{\circ} \mathrm{C}$ showed that the metal catalyst was not volatile and thus remain as residue. Thus, the weight loss indicates the purity and yield of the CNT and the higher the weight loss, the higher was the purity of CNTs. Based on the TGA analysis, we concluded that the optimized run yields a CNTs batch, which is almost 95\% pure.

\section{Purification of skim latex serum protein}

Chromatography of both small molecules and macromolecules was widespread in biochemistry. Moreover, most common techniques of these two techniques used were Ion Exchange Chromatography (IEC) and Hydrophobic Interaction Chromatography (HIC). Moreover, IEC uses chromatography media that were able to separate molecules based on charges, whereas HIC uses chromatography media that was able to separate molecules according to the degree of hydrophobicity. According to study, we used two different types of CNTs batches as the chromatographic media to separate skim latex serum. Moreover, guided by the functional groups available on the surface, we used CNTs differently; functionalized CNTs as IEC media and raw CNTs as HIC media.

After producing enough, followed by the step of an acid purifying and functionalization, CNTs were used as the chromatographic column media in two ways, namely non-functionalized and functionalized. Thus, guided by the available functional group on the CNTs surfaces, the process of purification of proteins were either conducted as in HIC or IEC. Moreover, the data produced from the AKTA prime is called chromatogram. Thus, it was a graph that monitors the signal in the UV detector over time. The detector was a device that measures the absorbance at $280 \mathrm{~nm}$ of the flow and through that it flows out of the column. Moreover, the signal increase and cause the chromatogram to 
display a "peak". Moreover, each peak in the chromatogram indicates the presence of proteins in the sample. Thus, the chromatogram that results from running the experiments consists of two peaks; the first one was designated to the unbounded protein and the second one to the eluted proteins. Based on experiments, the response to be monitored was the area under the curve of the second peak. This is because, the second peak was the measure of positive interaction or binding that occurs between proteins and the column media. Moreover, a large second peaks indicate a good interaction of protein with CNTs, which when carefully eluted would resolve in enhanced purification. Thus, the area under the curve of the second peak was automatically generated from the analyzed chromatogram data.

\section{Protein purification using non functionalized CNTs}

As the main functional group that exists on the surface in nonfunctionalized CNTs was carbon, which was hydrophobic, protein purification was carried out as according to the Hydrophobic Interaction Chromatography (HIC). Moreover, protein separation by hydrophobic interaction chromatography was dependent upon interactions between the protein itself, the CNTs matrix and the surrounding solvent which was usually aqueous. Moreover, increasing the concentration of buffer salt of a solution, with the addition of a neutral salt (e.g. ammonium sulphate or sodium chloride) increased the hydrophobicity of protein molecules that explained the hydration of salt ions in solution results, in an ordered shell of water molecules forming around each ion. Thus, it attracted water molecules, which in turn helps to unmask hydrophobic domains on the surface of the protein. Moreover, the increased in concentration of buffer salt enhance the surface hydrophobicity of protein molecules. Based on studies, the neutral salt sodium chloride results showed that the efficiency of protein binding to the column was less, because less ionic strength. Whereas, $2 \mathrm{M}$ ammonium sulphate was the best salt concentration for purification of protein from skim latex because it high concentration of buffer salt. Thus, it enhanced the surface hydrophobicity of protein molecules. Moreover, protein samples were therefore best applied to hydrophobic interaction columns under conditions of high concentration of buffer salt. As they percolated through the column, proteins might be retained via hydrophobic interactions.

In HIC, the attraction was between the hydrophobic side chain of amino acid that made up protein and the hydrophobic molecules of the chromatographic media (stationary phase). Moreover, the salt concentration decreased during the elution period, the surface of water molecules became a mask. Thus, hydrophobic domains on the surface of protein made the binding tighter on the surface of CNTs. Figure 7 shows a protein separation profile on non-functionalized CNTs, performing as an HIC media. Moreover, bound proteins were eluted by decreasing the concentration of the neutral salt. Thus, elution of two peaks as appeared they were labeled as for unbound (U) proteins and as bound proteins (B). Moreover, unbound protein might be hydrophilic and thus had no interaction with the hydrophobic CNT matrix, thus washed out immediately in the early stage of the elution. Thus, bound proteins were hydrophobic proteins which get bounded and were only eluted by decreasing the concentration of neutral salt. When the concentration of neutral salt was decreased, the protein hydrophobic surfaces were mask, pumping them to be released from CNTs matrix. Moreover, the less hydrophobic the protein would be eluted first and the most hydrophobic protein would be eluted last and thus the phenomena would separate the hydrophobic protein according to the charge of its hydrophobicity. Thus, area under the peak two or unbounded protein peak was the response to be considered when evaluating the efficiency of purification values. Moreover, the results shows that besides the concentration of added neutral salt, $\mathrm{pH}$ and concentration of the running buffer do influenced the level of binding protein thus, the difference in the area under the curve of unbound protein peak, $\mathrm{pH}$ and concentration of running buffer. Moreover, proteins are amphoteric molecules contain large number of acid and basic groups on the surface. Thus, the changes vary with $\mathrm{pH}$ and salt concentration of the environment, which would affect the total net charge of the protein [30] although the changes would be hidden, once neutral salt were added, the full net effect of hydrophobicity would be different with different $\mathrm{pH}$ and the salt concentration of running buffer.

\section{Protein purification using functionalized CNTs}

Based on the study, the capacity of protein purification using CNT as media in IEC was evaluated. Moreover, IEC used functionalized $\mathrm{CNT}$ as the chromatographic media to separate molecules based on charges. Thus, the functional groups on the surface of CNT were amine groups which were attached between amine group and CNT surface. Moreover, the principle of IEC which was negatively charged sample components were absorbed on the stationary phase and thus separated from positively charged and uncharged sample components. Moreover the absorbed components were eluted by increasing the concentration

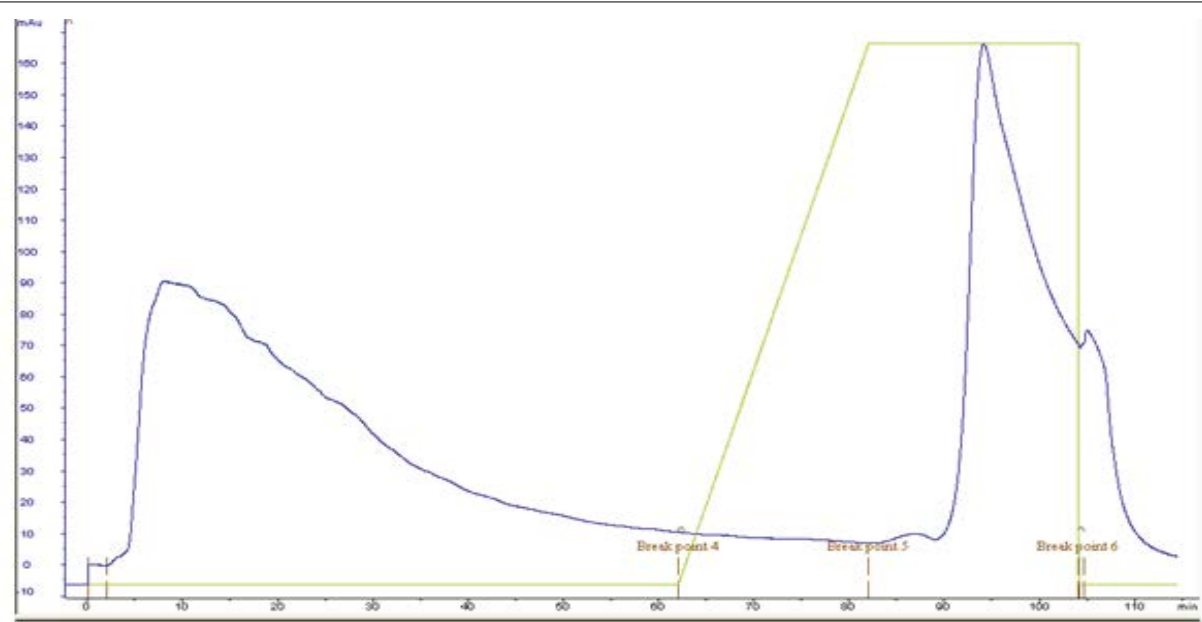

Figure 7: Chromatographic protein profile of skim latex serum on Non-functionalized CNTs as media; U- unbound protein, B-bound protein. 
of buffer salt of the mobile phase matrix that contained covalently attached positive group. When the protein purification, the functional group exists on the surface of CNTs, which was positively charge and negatively charge protein molecules would be interaction between functional groups protein side chains was temporary ionic interaction between charges and functional group. Based on the Figure 8, shows a protein separation profile on functionalized CNTs, performing as IEC media. Moreover, bound proteins were eluted by increasing the concentration of the neutral salt. Thus, the area under the curves of the protein profiles during elution when compared, suggest that nonfunctionalized CNTs performed more efficiently as HIC media than functionalized CNTs as IEC media. Moreover, unbound protein has less positively charge bound to the column in the early stage of graph. Thus, bound protein has highly negative charge, which was eluted by increasing the concentration of the neutral salt. Moreover, the efficiency of purification using functionalized CNTs was less as observed from area under the elution peak where very slight protein bound to the column. However, the capacity was dependent on $\mathrm{pH}$ and concentration of buffer salt. Thus, purification process using covalent functionalization of CNTs was less as compared to non-functionalization CNTs.

According to Table 2 shows that area under the curve of the second peak was higher (1875.58) in run 4 when $\mathrm{pH} 7$ with concentration of running buffer salt is $50 \mathrm{mM}$, Tris $\mathrm{HCl}$ with added neutral salt ammonium sulphate of $2 \mathrm{M}$. Moreover, the smallest area (4.56) was at $\mathrm{pH} 5$ with $150 \mathrm{mM}$ citric acid buffer with $1 \mathrm{M} \mathrm{NaCl}$. When the $\mathrm{pH}$ increased the area under the curve of the second peak decreased it could be observed at $\mathrm{pH} 9$ with concentration of running buffer $150 \mathrm{mM}$ Tris $\mathrm{HCl}$. When the concentration of buffer ion increased the binding interaction to the column decrease it could be seen from with $100 \mathrm{mM}$ and $150 \mathrm{mM}$ the area under the peak values were low compared to concentration of buffer of running buffer $50 \mathrm{mM}$. Identical trends for concentration of different neutral salt increased the binding capacity to the column high, It could be observed 2 different neutral salt with concentration of buffer salt ( $1 \mathrm{M}$ to $2 \mathrm{M})$ more the binding interaction took place at higher concentration of neutral salt. According to the studies sodium chloride the binding interaction was low as compared to ammonium sulphate.

\section{The effect of $\mathrm{pH}$ on purification method}

Proteins are amphoteric molecules containing a large number of acid and basic groups, mainly situated on their surface. Moreover, the change in these groups would vary, according to their acid dissociation constants, with the $\mathrm{pH}$ of their environment. This would affect the total net charge of the protein and the distribution of charge on their exterior surfaces, in addition to the reactivity of the catalytically active groups. These effects were especially important in the neighborhood of the active sites. Taken together, the changes with $\mathrm{pH}$ affect the activity, structural stability and solubility of the proteins. There would be a $\mathrm{pH}$, characteristic of each protein at which the net charge on the molecules was zero. This was called the isoelectric point (pI), at which the protein generally has a minimum solubility in aqueous solutions [31] Moreover, protein possesses a net charge in solution, dependent upon

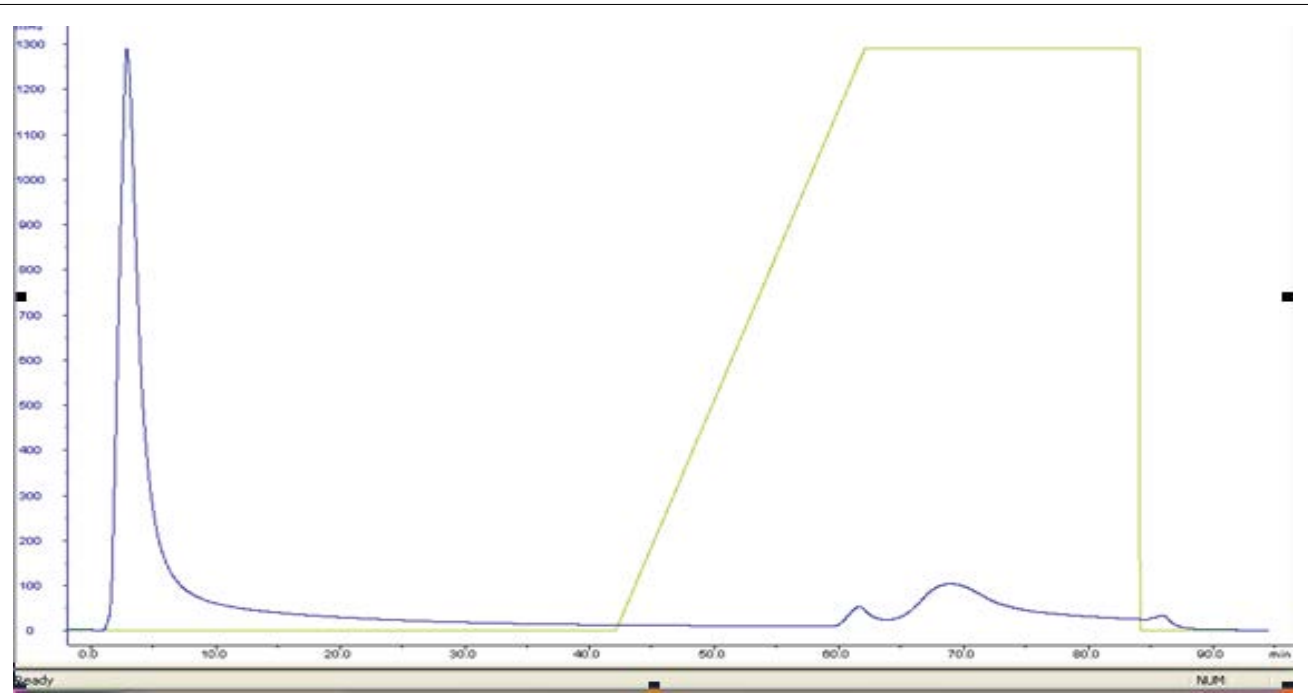

Figure 8: Chromatographic protein profile skim latex serum on functionalized CNTs as media; U-unbound protein, B-bound protein

\begin{tabular}{|c|c|c|c|c|c|c|c|}
\hline Run & Buffer & $\mathrm{pH}$ & $\begin{array}{l}\text { Concentration of buffer salt } \\
\qquad(\mathrm{mM}\end{array}$ & 1AS & 2AS & $1 \mathrm{NaCl}$ & $2 \mathrm{NaCl}$ \\
\hline 1 & $2 \mathrm{AS}+$ Citric acid/sodium citrate $50 \mathrm{M}$ & 5 & 50 & 68.36 & 778.87 & 5.66 & 18.39 \\
\hline 2 & $2 \mathrm{AS}+$ Citric acid/sodium citrate $100 \mathrm{M}$ & 5 & 100 & 39.76 & 1061.93 & 16.95 & 45.28 \\
\hline 3 & $2 \mathrm{AS}+$ Citric acid/sodium citrate $150 \mathrm{M}$ & 5 & 150 & 119.38 & 966.63 & 4.56 & 85.98 \\
\hline 4 & $2 \mathrm{AS}+50 \mathrm{~m}$ Tris $\mathrm{HCl}$ & 7 & 50 & 42.89 & 1875.58 & 85.09 & 205.51 \\
\hline 5 & $2 \mathrm{AS}+100 \mathrm{M}$ Tris $\mathrm{HCl}$ & 7 & 100 & 352.22 & 1174.42 & 2.12 & 79.92 \\
\hline 6 & $2 \mathrm{AS}+150 \mathrm{M}$ Tris $\mathrm{HCl}$ & 7 & 150 & 576.46 & 906.18 & 18.27 & 117.52 \\
\hline 7 & $2 \mathrm{AS}+50 \mathrm{M}$ Tris $\mathrm{HCl}$ & 9 & 50 & 156.36 & 674.13 & 23.58 & 86.23 \\
\hline 8 & $2 \mathrm{AS}+100 \mathrm{M}$ Tris $\mathrm{HCl}$ & 9 & 100 & 500.85 & 959.43 & 356 & 9.89 \\
\hline 9 & $2 \mathrm{AS}+150 \mathrm{M}$ Tris $\mathrm{HCl}$ & 9 & 150 & 57.62 & 1210.68 & 243 & 26.99 \\
\hline
\end{tabular}

Table 2: Area under the peak value at different buffer concentration. 
the $\mathrm{pH}$ and their structure and isoelectric point. In the solutions of $\mathrm{pH}$ below their isoelectric point they would be positively charged and bind to cation exchangers whereas in solutions of $\mathrm{pH}$ above their isoelectric point they would be negatively charged and bind to anion exchangers. Thus, protein purification during HIC or IEC media, $\mathrm{pH}$ was very important parameter during the method of purification. Moreover, it has been observed that there was a general decrease in the strength of interaction between proteins and hydrophobic matrices with increasing $\mathrm{pH}$. This was presumably caused by the increasing hydrophobicity of the protein resulting from the titration of charge groups. This general trend was supplemented by the fact that $\mathrm{pH}$ effects were different for different proteins. Thus, it was possible to modify elution profiles and improve separation by carrying out the procedure at various $\mathrm{pH}$ values. Moreover, it is important at which $\mathrm{pH}$ value of protein may precipitate near their isoelectric points (pIs). In IEC, proteins are most commonly eluted by increasing the salt concentration of running buffer. Moreover, protein can also be eluted by a change in buffer $\mathrm{pH}$, raising the $\mathrm{pH}$ to elute from cation exchangers and lowering the $\mathrm{pH}$ to elute from anion exchangers. Thus, the purification process results showed that the effect of $\mathrm{pH}$ is an important factor for the purification of protein. Moreover, $\mathrm{pH}$ ranging between 5, 7 and 9 with different neutral salt of ammonium sulphate and sodium chloride was used. Thus, protein binding took place during column chromatography depends on the suitable $\mathrm{pH}$ and concentration of buffer salt. CNTs as HIC media has been observed to give the highest protein binding during the elution period which has the highest area under the peak at $\mathrm{pH} 7$, as shown in Table 2. According to the results showed that the efficiency of protein binding to the column obtained at pH 5 and 9 was less and the area under the peak value was also less compared to $\mathrm{pH} 7$. Hence, $\mathrm{pH}$ played an important role during protein purification from skim latex serum.

\section{The effect of concentration of buffer salt on purification method}

The ionic strength of the solution is very important parameter affecting protein activity. This was especially noticeable where catalysis depends on the movement of charge molecules relative to each other. Thus, binding of charge substrates to protein and the movement of charge groups within a catalytic active site would be influenced by the ionic composition of the medium. Moreover, the effect of salt composition on the protein retention follows the order of the salts in the lyotropic series for the precipitation of proteins or for their positive influence in increasing the molar surface tension of water [32]. Thus, concentration of salt by running buffer such as sodium chloride and ammonium sulphate was the most effective to promote ligand-protein interactions, because the higher 'salting-out' or molar surface tension increment effects. Moreover, a change of the salt type in the eluent results in significant alterations not only in the overall retention of the proteins, as well as in the selectivity of the separations [33]. Thus, the concentration of salt strongly influences the selectivity in protein adsorption and this influence was different and dependent both on the stationary phase and the buffer salts [34]. During column chromatography, the use of high salt concentration on the equilibration buffer and the sample solution promotes the ligand-protein interactions and consequently the protein retention. Moreover, the amount of the bound protein increases linearly with the enhancement in ionic strength and continues to increase in an exponential manner at still higher concentration. Thus, the adsorbed proteins were eluted by stepwise or gradient elution at decreasing salt concentration in the eluent. Moreover, the neutral salts used in HIC must be highly soluble to avoid salt precipitation when they were added in high concentration to the eluent to drive the hydrophobic interaction.
Thus, the viscosity, UV transparency and stability at alkaline $\mathrm{pH}$ values were other important factors for choosing the neutral salts [35]. Based on results showed that, concentration of buffer salt played an important role in column chromatography; it could be observed that concentration of running buffer varied from $50 \mathrm{mM}, 100 \mathrm{mM}$ and $150 \mathrm{mM}$. Based on the result obtained at lower concentrations of running buffer $50 \mathrm{mM}$ give highest area under the elution period were observed, whereas at higher concentration of running buffer $100 \mathrm{mM}$ and $150 \mathrm{mM}$ give less area under the elution period as shown in Table 2. Therefore, the effect of concentration of running buffer was essential during the process of purification of protein from skim latex serum.

\section{The effect of concentration of neutral salt}

The effects of neutral salts on protein solubility (salting-out) and on retention in HIC. Moreover, they have shown the similarity in both processes and have attributed the quantitative relationship between the salt concentration and the protein-protein contacts in salting-out or protein-ligand contacts in HIC, to the changes in surface tension. Based on the free-energy change upon solute binding was related to the process of the solute solvation, the stationary-phase ligands and the complex of both. In the solvation process, first we have to consider the formation of a cavity in the solvent with the same size of the solute molecule, then the solute enters the cavity and interacts with its environment by electrostatic and van der Waals forces. Moreover, hydration models referring the preferential interaction of proteins with salts and the effect of the salt on the protein solubility [36]. Thus, it showed that some salts such as $\mathrm{MgCl}_{2}$, despite increasing the surface tension of water as other salts such as sodium sulphate and phosphates, they promote the protein solubility and do not enhance the protein binding to hydrophobic stationary phases, as much as expected from the surface tension increment. Moreover, the salts such as sodium sulphate or phosphates are excluded from the immediate domain of the proteins in concentrated solutions due to the proteins are preferentially hydrated. Thus, the presence of the salts increases the free energy of the proteins and this free energy augmentation was proportional to the hydrophobic surface area of the protein molecules. Moreover, the intermolecular association of hydrophobic groups minimizes the increase in free energy by decreasing the hydrophobic contact area of the protein with the polar solvent media. Therefore, when a hydrophobic stationary phase was introduced into the system, proteins bound to the stationary phase because it minimizes the surface contact area of protein and adsorbent with the salt solvent medium and produces a minimum increase in free energy. Moreover, in a medium of high salt concentration the bound form of protein is thermodynamically more stable than the unbound protein. This was explained the protein binding to hydrophobic stationary phases at high salt concentration. Thus, promoting the free state of the protein molecules that is thermodynamically more favorable than the bound state. This also explains why a certain type of salts promotes elution of proteins in a hydrophobic column. Moreover, the effect of concentration of neutral salt was also an important factor during protein purification. Thus, different concentration of neutral salt, such as ammonium sulphate and sodium chloride was studied as HIC media. According to the results showed based on the effect of concentration of neutral salt, protein binding took place during the elution period. The concentration of neutral salt varied from $1 \mathrm{M}$ to $2 \mathrm{M}$, from the observation the protein binding in HIC with $2 \mathrm{M}$ ammonium sulphate gave higher binding protein than $2 \mathrm{M}$ sodium chloride. This is because the high concentration of ammonium sulphate which made protein binding efficiency higher compared to sodium chloride. According to the data it could be clearly seen as if the concentration of neutral salt was high the binding capacity of protein to the column 
Citation: Mubarak NM, Faridah Y (2015) Protein Purification in Chromatographic Media using Multiwall Carbon Nanotubes. J Bioprocess Biotech 5: 214 doi: $10.4172 / 2155-9821.1000214$

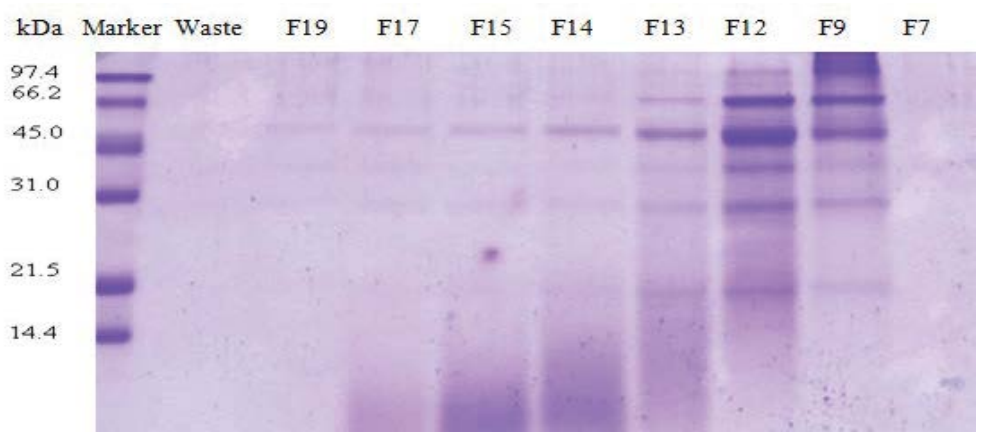

Figure 9a: Non -Functionalization of SDS -PAGE M-molecular weight marker, D-original skim latex serum and F-fraction.

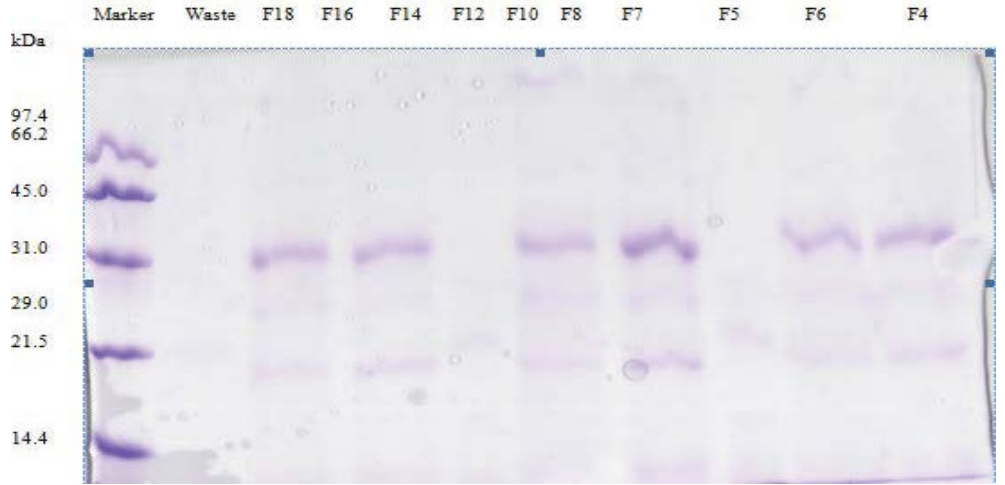

Figure 9b: Functionalization of SDS-PAGE.M-molecular weight marker, D-original skim latex serum and F-fraction.

was also high. Thus, the lower the concentrations of neutral salt give lower binding capacity to the column. Therefore concentration of neutral salt was very important during protein purification. Moreover, $2 \mathrm{M}$ ammonium sulphate allows for high efficiency of protein binding during HIC media.

\section{Analysis of protein by SDS-PAGE}

Protein analysis on fractions collected during the chromatography was made on Sodium dodecyl sulfate-Polyacrylamide gel electrophoresis (SDS-PAGE). According to Figures 9A and 9b show protein profile of fraction from functionalized CNTs with ammonium sulphate as the neutral salt, functionalized CNTs with $\mathrm{NaCl}$ as neutral salt and nonfunctionalized CNTs, respectively. Moreover, protein bands were compared to unchromatographed skim latex serum, labeled as D in the figures, Bound proteins in all cases were observed to be about medium range having molecular weights between $30-66 \mathrm{KDa}$ as shown in the figures.

\section{Conclusion}

CNTs has been successfully produced by DS-CVD and the statistical analysis reveals that the optimized conditions for the best yield CNTs production was $750^{\circ} \mathrm{C}$ reaction temperature, 30 minutes reaction time with gases flow rates of 60 and $170 \mathrm{ml} / \mathrm{min}$ for $\mathrm{C}_{2} \mathrm{H}_{2}$ and $\mathrm{H}_{2}$ respectively. Moreover, based on TGA analysis shows that the purity of CNTs produced as about 95\% purity. Thus, FESEM and TEM analyses reveal that the uniformly dispersed CNTs have diameters ranging from 35 to $45 \mathrm{~nm}$. Our results proved that non functionalized CNTs behaves like hydrophobic interaction chromatography, whereas functionalized CNTs behaves like Ion Exchange Chromatography (IEC) matrix during the purification of protein. Moreover, based on the results show that as usual the efficiency of the protein purification was dependent upon $\mathrm{pH}$ and the ionic strength of the running buffer.

\section{Acknowledgement}

The authors are grateful to IIUM University for their cooperation and support to carry out this research.

\section{References}

1. lijima S (1991) Helical microtubules of graphitic carbon. Nature 354: 56-58.

2. Dresselhaus MS, Dresselhaus G, Avouris P (2001) Carbon Nanotubes: Synthesis, Structure, Properties, and Applications, Germany: Springer-Verlag Berlin Heidleber G. 1-9.

3. Davis JJ, Coles RJ, Hill HAO (1997) Protein Electrochemistry at Carbon Nanotube Electrodes. J Electroanal Chem 440: 279-282.

4. Sakar A, Banerjee RA (2004) A quantitative method for characterization of carbon nanotubes for hydrogen storage. Int J Hydrogen Energy 29: 1487-1491.

5. Mintmire JW, Dunlap BI, White CT (1992) Are fullerene tubules metallic? Phys Rev Lett 68: 631-634.

6. Bonard JM, Salvetat JP, Stockli T, de Heer WA, Forro L, et al. (1998) Filed emission from single-wall carbon nanotube films. Appl Phy Lett 73: 918-920.

7. Derycke V, Martel R, Appenzeller J, Avouris P (2001) Carbon nanotube interaand intermolecular logic gates. Nano Lett 1: 453-456.

8. Kong J, Franklin NR, Zhou C, Chapline MG, Peng S, et al. (2000) Nanotube molecular wires as chemical sensors. Science 287: 622-625.

9. Chen P, Wu X, Lin J, Tan KL (1999) High $\mathrm{H}_{2}$ uptake by alkali-doped carbon nanotubes under ambient pressure and moderate temperatures. Science 285 91-93.

10. Liu C, Fan YY, Liu M, Cong HT, Cheng HM, et al. (1999) Hydrogen storage in single-walled carbon nanotubes at room temperature. Science 286: 1127-1129. 
Citation: Mubarak NM, Faridah Y (2015) Protein Purification in Chromatographic Media using Multiwall Carbon Nanotubes. J Bioprocess Biotech 5: 214 doi: 10.4172/2155-9821.1000214

Page 9 of 9

11. Dai H, Hafner H, Rinzler AG, Colbert DT, Smalley RE (1996) Nanotubes as nanoprobes in scanning probe microscopy. Nature 384: 147-149.

12. Journet C, Bernier P (1998) Production of carbon nanotubes. Appl Phys A 67 $1-9$

13. Thess A, Lee R, Nikolaev P, Dai H, Petit P, et al. (1996) Crystalline Ropes of Metallic Carbon Nanotubes Science 273: 483-487.

14. Bethune DS, Kiang CH, deVries MS, Gorman G, Savoy R, et al. (1993) Cobaltcatalyzed growth of carbon nanotubes with Single-atomic-layer. Nature 363 605-607.

15. Akbar NS, Rahman S, Ellahi R, Nadeem S (2014) Nano fluid flow in tapering stenosed arteries with permeable walls. International Journal of Thermal Sciences 85: 54-61.

16. Akbar NS, Raza M, Ellahi R (2014) Influence of heat generation and heat flux on peristaltic flow with interacting nanoparticles. Eur Phys J Plus 129: 1-15.

17. Akbar NS, Raza M. Ellahi R (2014) Interaction of nanoparticles for the peristaltic flow in an asymmetric channel with the induced magnetic field. Eur Phys J Plus 129: $1-12$

18. Ellahi R (2013) The effects of MHD and temperature dependent viscosity on the flow of non-Newtonian nanofluid in a pipe: Analytical solutions. Applied Mathematical Modelling 37: 1451-1467.

19. Ellahi R, Aziz S, Zeeshan A (2013) Non-Newtonian nanofluid flow through a porous medium between two coaxial cylinders with heat transfer and variable viscosity. Journal of Porous Media 16: 205-216.

20. Ellahi R, Hassan M, Zeeshan A (2015) Shape effects of nanosize particles in $\mathrm{Cu}-\mathrm{H}_{2} \mathrm{O}$ nanofluid on entropy generation. International Journal of Heat and Mass Transfer 81: 449-456.

21. Ellahi R, Raza M, Vafai K (2012) Series solutions of non-Newtonian nanofluids with Reynolds' model and Vogel's model by means of the homotopy analysis method. Mathematical and Computer Modelling 55: 1876-1891.

22. Rashidi S, Dehghan M, Ellahi R, Riaz M, Jamal-Abad MT (2015) Study of stream wise transverse magnetic fluid flow with heat transfer around an obstacle embedded in a porous medium. Journal of Magnetism and Magnetic Materials 378: 128-137.

23. Sheikholeslami M, Bandpy MG, Ellahi R, Zeeshan A (2014) Simulation of MHD CuO-water nanofluid flow and convective heat transfer considering Lorentz forces. Journal of Magnetism and Magnetic Materials 369: 69-80.
24. Sheikholeslami M, Ellahi R, Ashorynejad H Domairry G, Hayat T (2014) Effects of heat transfer in flow of nanofluids over a permeable stretching wall in a porous medium. Journal of Computational and Theoretical Nanoscience 11 : 486-496.

25. Sheikholeslami M, Ellahi R, Hassan M, Soleimani S (2014) A study of natural convection heat transfer in a nanofluid filled enclosure with elliptic inner cylinder. International Journal of Numerical Methods for Heat \& Fluid Flow 24: 1906-1927.

26. Sheikholeslami M, Ganji DD, Javed MY, Ellahi R (2015) Effect of therma radiation on magnetohydrodynamics nanofluid flow and heat transfer by means of two phase model. Journal of Magnetism and Magnetic Materials 374: 36-43.

27. Sinnott SB (2002) Chemical functionalization of carbon nanotubes. J Nanosci Nanotechnol 2: 113-123.

28. Yusof F, Ward MA, Walker J (1998) Purification characterization of an inhibitor of rubber biosynthesis from C-serum of Hevea brasiliensis latex. J Rubber Research 1: 95-110.

29. Wang SJ, Hu WX, Liao DW, Ng CF, Au C (2005) In situ FTIR studies of no reduction over carbon nanotube. Catalysis Today 93-95: 711-714.

30. Xia F, Nagrath D, Cramer SM (2005) Effect of pH changes on water release values in hydrophobic interaction chromatographic systems. J Chromatogr A 1079: $229-235$

31. Martin C, Christopher B (1990) Enzyme Technology. E-books category United Kingdom. Cambridge University Press.

32. Melander W, Horváth C (1977) Salt effect on hydrophobic interactions in precipitation and chromatography of proteins: an interpretation of the lyotropic series. Arch Biochem Biophys 183: 200-215.

33. Rippel G, Szepesy L (1994) Hydrophobic interaction chromatography of proteins on an Alkyl-Superose column. J Chromatography A 664: 27-32.

34. Oscarsson S, Kårsnäs $P$ (1998) Salt-promoted adsorption of proteins onto amphiphilic agarose-based adsorbents. II. Effects of salt and salt concentration. J Chromatogr A 803: 83-93.

35. Narhi LO, Kita Y, Arakawa T (1989) Hydrophobic interaction chromatography in alkaline $\mathrm{pH}$. Anal Biochem 182: 266-270.

36. Arakawa T (1986) Thermodynamic analysis of the effect of concentrated salts on protein interaction with hydrophobic and polysaccharide columns. Arch Biochem Biophys 248: 101-105. 